\title{
The nuclear receptor PPARß/ס programs muscle glucose metabolism in cooperation with AMPK and MEF2
}

\author{
Zhenji Gan, ${ }^{1,3}$ Eileen M. Burkart-Hartman, ${ }^{2,3,4}$ Dong-Ho Han, ${ }^{2}$ Brian Finck, ${ }^{2}$ Teresa C. Leone, ${ }^{1,2}$ \\ Emily Y. Smith, ${ }^{1}$ Julio E. Ayala, ${ }^{1}$ John Holloszy, ${ }^{2}$ and Daniel P. Kelly ${ }^{1,2,5}$ \\ ${ }^{1}$ Diabetes and Obesity Research Center, Sanford-Burnham Medical Research Institute, Orlando, Florida 32827, USA: \\ ${ }^{2}$ Department of Medicine, Washington University School of Medicine, St. Louis, Missouri 63110, USA
}

To identify new gene regulatory pathways controlling skeletal muscle energy metabolism, comparative studies were conducted on muscle-specific transgenic mouse lines expressing the nuclear receptors peroxisome proliferator-activated receptor $\alpha$ (PPAR $\alpha$; muscle creatine kinase [MCK]-PPAR $\alpha)$ or PPAR $\beta / \delta$ (MCK-PPAR $\beta / \delta)$. $M C K-P P A R \beta / \delta$ mice are known to have enhanced exercise performance, whereas MCK-PPAR $\alpha$ mice perform at low levels. Transcriptional profiling revealed that the lactate dehydrogenase $b(L d h b) / L d h a$ gene expression ratio is increased in MCK-PPAR $\beta / \delta$ muscle, an isoenzyme shift that diverts pyruvate into the mitochondrion for the final steps of glucose oxidation. PPAR $\beta / \delta$ gain- and loss-of-function studies in skeletal myotubes demonstrated that $\operatorname{PPAR} \beta / \delta$, but not PPAR $\alpha$, interacts with the exercise-inducible kinase AMP-activated protein kinase (AMPK) to synergistically activate $L d h b$ gene transcription by cooperating with myocyte enhancer factor 2A (MEF2A) in a PPAR $\beta / \delta$ ligand-independent manner. MCK-PPAR $\beta / \delta$ muscle was shown to have high glycogen stores, increased levels of GLUT4, and augmented capacity for mitochondrial pyruvate oxidation, suggesting a broad reprogramming of glucose utilization pathways. Lastly, exercise studies demonstrated that MCK-PPAR $\beta / \delta$ mice persistently oxidized glucose compared with nontransgenic controls, while exhibiting supranormal performance. These results identify a transcriptional regulatory mechanism that increases capacity for muscle glucose utilization in a pattern that resembles the effects of exercise training.

[Keywords: muscle; exercise; nuclear receptors; glucose metabolism; gene regulation]

Supplemental material is available for this article.

Received September 2, 2011; revised version accepted November 2, 2011.

Muscle performance and resistance to fatigue are determined, in part, by the capacity to burn the chief fuelsfatty acids (FAs) and glucose-in order to generate the ATP needed for consistent mechanical function (Coggan 1991; Holloszy et al. 1998; Burke and Hawley 1999; Hawley 2002; Hargreaves 2004). The capacity for muscle glucose utilization is an important determinant of muscle fitness. Endurance training enhances insulin-dependent and -independent muscle glucose uptake and utilization (Ivy and Holloszy 1981; Richter et al. 1982; Hayashi et al. 1997; Holloszy 2005), resulting in improvements in whole-body insulin sensitivity (DeFronzo et al. 1985; Treadway et al. 1989; Goodyear et al. 1995; Wojtaszewski et al. 1997, 2000a). Evidence is emerging that the effects of exercise training on muscle glucose uptake involve events downstream

\footnotetext{
${ }^{3}$ These authors contributed equally to this work.

${ }^{4}$ Present address: Abbott Laboratories, Abbot Park, Illinois 60064, USA

${ }^{5}$ Corresponding author.

E-mail dkelly@sanfordburnham.org.

Article published online ahead of print. Article and publication date are online at http://www.genesdev.org/cgi/doi/10.1101/gad.178434.111.
}

from the exercise-stimulated kinase AMP-activated protein kinase (AMPK) and related cellular signaling pathways (Witczak et al. 2008). Delineation of the molecular regulatory pathways involved in the beneficial effects of exercise on muscle glucose metabolism could yield novel therapeutic targets aimed at the prevention or treatment of obesity-related insulin resistance and its consequences.

The capacity of muscle to burn FAs is determined, in part, at the level of gene expression. A transcriptional regulatory circuit involved in the control of skeletal muscle FA utilization has been delineated. The peroxisome proliferatoractivated receptors (PPARs) $\alpha$ and $\beta$ (also known as $\delta$ ), members of the nuclear receptor superfamily, have been shown to regulate genes involved in muscle FA uptake and catabolism (Desvergne and Wahli 1999). The activity of the PPARs is regulated at multiple levels, including availability of activating ligands (endogenous FA/lipid moieties) and coactivators such as PPAR $\gamma$ coactivator- $1 \alpha$ (PGC- $1 \alpha$ ) (Desvergne and Wahli 1999; Vega et al. 2000; Wende et al. 2007; Madrazo and Kelly 2008; Schupp and Lazar 2010). Most of the work relevant to the control of cellular fuel 
metabolism by PPARs has focused on PPAR $\alpha$. PPAR $\alpha$ activates transcription of genes involved in numerous steps of cellular FA uptake and oxidation in muscle, liver, and heart (Gulick et al. 1994; Leone et al. 1999; Finck et al. 2002, 2005; Madrazo and Kelly 2008; Montagner et al. 2011). Thus, activation of PPAR $\alpha$ serves to reprogram the skeletal myocyte for high-capacity FA burning.

$\operatorname{PPAR} \beta$ shares many gene targets with $\operatorname{PPAR} \alpha$, including those involved in cellular FA utilization (Desvergne and Wahli 1999; Gilde et al. 2003; Huss and Kelly 2004; Montagner et al. 2011). Surprisingly, however, transgenic mice with skeletal muscle-specific forced expression of either PPAR $\alpha$ or PPAR $\beta$ exhibit remarkably different phenotypes (Luquet et al. 2003; Wang et al. 2004; Finck et al. 2005), suggesting that the two structurally related nuclear receptors regulate a subset of unique downstream genes and biological functions. Specifically, muscle-specific PPAR $\alpha$ (muscle creatine kinase [MCK]-PPAR $\alpha$ ) transgenic mice exhibit myocyte triacylglyceride (TAG) accumulation, high muscle FA oxidation (FAO) rates, glucose intolerance, and mild insulin resistance (Finck et al. 2005). In striking contrast, muscle-specific PPAR $\beta$ mice (MCK-PPAR $\beta$ ) develop many features of an exercise-trained phenotype ("marathon mice"), including increased endurance, increased mitochondrial capacity, an oxidative fiber type shift, and enhanced insulin sensitivity (Luquet et al. 2003; Wang et al. 2004).

The contrasting phenotypes of the MCK-PPAR lines, while clearly representing extremes due to genetic manipulation of transcription factor expression, afford a unique opportunity to identify new downstream gene regulatory mechanisms involved in the chronic control of muscle energy metabolism. Moreover, delineation of the mechanisms whereby $\operatorname{PPAR} \alpha$ and $\operatorname{PPAR} \beta$ regulate distinct gene targets is an important question for the nuclear receptor biology field. Therefore, we embarked on a study to compare and contrast the gene expression profiles and metabolic phenotypes of closely matched MCK-PPAR lines. Our results indicate that, in addition to controlling muscle FA metabolism, PPAR $\beta$ activates a program involved in muscle glucose utilization in a pattern that is strikingly similar to the effects of exercise training. Specifically, PPAR $\beta$ activates transcription of the gene encoding lactate dehydrogenase B (LDHB), which catalyzes a key nodal point for increasing capacity for glucose oxidation by diverting glucose and lactate into the formation of pyruvate for mitochondrial oxidation. This transcriptional regulatory mechanism, which is unique for PPAR $\beta$ (compared with $\operatorname{PPAR} \alpha$ ), involves cooperation with the exercise-induced kinase AMPK and the muscle-enriched transcription factor myocyte enhancer factor 2 (MEF2).

\section{Results}

PPAR $\beta$ and PPAR $\alpha$ regulate distinct $L D H$ isoenzyme shifts

MCK-PPAR $\beta$ transgenic lines were established using the same strategy as that for MCK-PPAR $\alpha$ lines generated previously (Finck et al. 2005). Three independent MCK-PPAR $\beta$ transgenic lines were established, with levels of expression ranging from high physiological (low expression [LE]) to supraphysiological (medium [ME] and high [HE] expression) (Supplemental Fig. 1A,B), corresponding to those of the MCK-PPAR $\alpha$ lines (Finck et al. 2005). The data shown here represent assessment of the $\mathrm{HE}$ lines unless indicated otherwise. Gene expression profiling studies conducted with RNA isolated from muscle of the MCK-PPAR $\beta$ and MCK-PPAR $\alpha$ mice, compared with corresponding nontransgenic littermate (NTG) controls, confirmed increased expression of many known PPAR target genes involved in cellular FAO in both lines (Supplemental Fig. 1C,D). Exercise studies using a motorized treadmill confirmed that MCK-PPAR $\beta$ mice ran longer distances than corresponding NTG controls using an endurance regimen (Supplemental Fig. 1E), consistent with the original observations by Wang et al. (2004) for the PPAR $\beta$ VP16 transgenic line. In contrast, MCK-PPAR $\alpha$ mice ran shorter distances than NTG controls (Supplemental Fig. 1E).

The gene expression profiling data sets were analyzed to identify metabolic genes that were differentially regulated in the two MCK lines. Comparative analysis identified several genes involved in glucose utilization pathways that were differentially regulated (Supplemental Fig. 2). Of particular interest was the expression pattern of the $L d h b$ (or Ldh2) and Ldha (or Ldh1) genes. Ldhb gene expression was increased, whereas Ldha gene expression was modestly decreased, in MCK-PPAR $\beta$ muscle, a pattern that was not observed for MCK-PPAR $\alpha$ (Supplemental Fig. 2). These results were of interest because the LDHB isoenzyme favors the reaction that converts lactate to pyruvate, which in turn provides substrate for the mitochondrial TCA cycle (glucose oxidation), whereas LDHA favors the reverse reaction to produce lactate from pyruvate generated by glycolysis (Fig. 1A). These findings were validated by quantitative RT-PCR (qRT-PCR) across several muscle types (Fig. 1B). The expected LDH isoenzyme activity shifts were confirmed by activity gel studies (Fig. 1C; Supplemental Fig. 3; data not shown).

\section{PPAR $\beta$ cooperates with AMPK and MEF2 to activate} Ldhb gene transcription

Evidence has emerged that AMPK serves as a transducer of exercise to increase muscle glucose uptake (Ren et al. 1994; Holmes et al. 1999; Ojuka et al. 2000; Holloszy 2005; Witczak et al. 2008). More recently, PPAR $\beta$ and AMPK $\alpha$ were shown to cooperate in the transcriptional regulation of several known PPAR target genes, including uncoupling protein $3(U c p 3)$ and lipoprotein lipase $(L p I)$ (Narkar et al. 2008). To assess the requisite role of PPAR $\beta$ in the control of $L d h b$ gene expression in the absence of overexpression and determine whether AMPK signaling is involved in this mechanism, PPAR $\beta$ loss-of-function studies were conducted in wild-type mouse primary skeletal myotubes. The effects of PPAR $\beta$ ligand (GW501516) and the AMPK activator AICAR were assessed alone and together in the presence or absence of PPAR $\beta$ shRNA-mediated knockdown. Consistent with previous results (Narkar et al. 2008), GW501516 and AICAR cooperated to increase expression of the Ucp3 gene, a known PPAR target-an 
A.
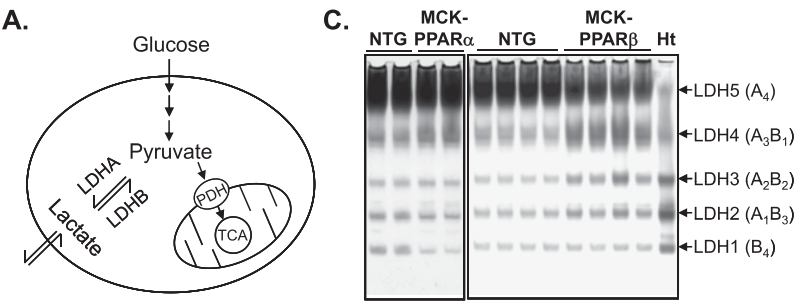

B.
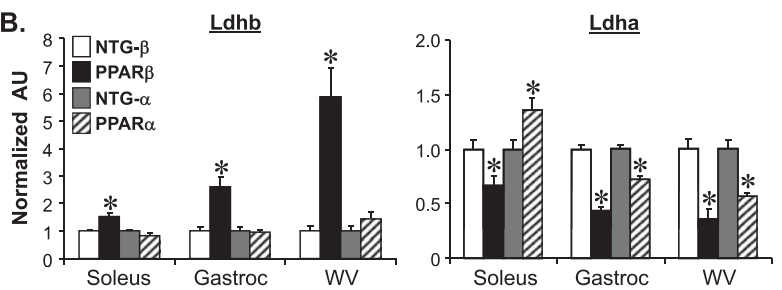

Figure 1. MCK-PPAR $\beta$ drives an LDHB/LDHA isoenzyme shift, reprogramming muscle for increased glucose oxidation. $(A)$ Schematic depicts the lactate- and glucose-derived pyruvate catabolic fates. The reaction catalyzed by LDH isoenzymes is shown with the $\mathrm{A}$ isoenzyme (LDHA) favoring pyruvate to lactate and the $\mathrm{B}$ isoenzyme (LDHB) favoring the reverse reaction. $(B)$ Results of qRT-PCR analysis of Ldha and Ldhb mRNA levels in soleus, gastrocnemius (Gastroc), and white vastus (WV) muscles from indicated mice ( $n \geq 6$ mice in each group). Values represent mean ( \pm SEM) shown as arbitrary units (AU) normalized $(=1.0)$ to the value of NTG control. $\left(^{*}\right) P<0.05$ compared with corresponding NTG control. $(C)$ A representative LDH isoenzyme activity gel is shown. Isoenzymes were separated by polyacrylamide gel electrophoresis using whole-cell extracts from NTG heart $(\mathrm{Ht}$, control) and gastrocnemius muscle from indicated mice ( $n \geq 3$ mice in each group). Note a distinct shift toward the LDHB-containing isoenzymes LDH4, LDH3, and LDH2, with a concomitant reduction in LDH5 (which lacks the $\mathrm{B}$ isoenzyme) in the MCK-PPAR $\beta$ samples.

effect that was abolished upon knockdown of PPAR $\beta$. Interestingly, $L d h b$ gene expression was activated by AICAR but not by the PPAR $\beta$ agonist GW501516 (Fig. 2A). PPAR $\beta$ knockdown modestly reduced basal $L d h b$ mRNA levels and completely abolished the AICAR-mediated stimulatory effect (Fig. 2A). These results further establish the relevance of PPAR $\beta$-mediated regulation of $L d h b$ gene expression and demonstrate the importance of PPAR $\beta /$ AMPK cooperativity in this mechanism.

We next sought to determine whether the AMPK signaling pathway was activated in MCK-PPAR $\beta$ muscle. Levels of phosphorylated AMPK $\alpha$ (p-AMPK $\alpha$ ) and acetyl-CoA carboxylase (p-ACC), a known AMPK target, were significantly increased in MCK-PPAR $\beta$ muscle (Fig. 2B). Levels of LKB1, an activating kinase upstream of AMPK, were not different in the transgenic and control muscle. However, levels of CaMKK $\alpha$, a second AMPK kinase (Hawley et al. 2005; Woods et al. 2005), were significantly increased in the MCK-PPAR $\beta$ muscle compared with control, but not in the MCK-PPAR $\alpha$ muscle (Fig. 2C). CaMKK $\beta$ protein levels were not detected by immunoblotting in these samples. These results indicate that the CAMKK $\alpha-\mathrm{AMPK}$ axis is activated in MCK-PPAR $\beta$ muscle in the absence of an exercise stimulus.
To further define the mechanism involved in the activation of $L d h b$ gene expression by PPAR $\beta$, the $L d h b$ gene promoter region was screened for putative PPAR $\beta$ occupation sites via chromatin immunoprecipitation (ChIP) in primary skeletal myotubes in which PPAR $\beta$ was overexpressed. One region, defined by primers amplifying a segment spanning -1228 to -1078 base pairs (bp) upstream of the transcription start site, was specifically enriched by the PPAR $\beta$ antibody (Supplemental Fig. 4). This region was notable for the lack of a consensus PPAR response element but the presence of a MEF2 recognition site (CTATTTATAG), which is highly conserved in the rat (CTATTTATAG) and human (ATAATTATAG) Ldhb gene promoter regions. Mef2 $a$ and Mef2c mRNA levels were modestly increased in MCK-PPAR $\beta$ muscle, whereas $\mathrm{Mef2a}$ gene expression was decreased in MCK-PPAR $\alpha$ muscle (Supplemental Fig. 5).

Additional ChIP experiments were conducted to determine whether PPAR $\beta$ and MEF2 co-occupy the region of the $L d h b$ promoter containing the MEF2-binding site. Antibodies to both PPAR $\beta$ and MEF2 precipitated this region of chromatin (Fig. 3A). As a control for specificity, ChIP experiments were also performed with a region of the $C p t 1 b$ gene promoter containing known PPAR and MEF2 response elements (Brandt et al. 1998; Baldan et al. 2004). Anti-PPAR $\beta$ and anti-MEF2 immunoprecipitated the relevant region in the $C p t 1 b$ promoter. In contrast, anti-PPAR $\beta$, but not anti-MEF2, immunoprecipitated the PPAR-responsive region of the $U c p 1$ gene promoter, which lacks a MEF2 site (Fig. 3A). These results strongly suggest that MEF2 is involved in the PPAR $\beta$-mediated regulation of $L d h b$ gene transcription. Consistent with this conclusion, siRNA-mediated knockdown of Mef2a transcript in skeletal myotubes resulted in diminished expression of Ldhb and the known MEF2A target Slc2a4 (GLUT4), but not Ldha (Fig. 3B).

A series of coimmunoprecipitation (co-IP) studies were conducted to determine whether AMPK participated directly in the PPAR $\beta / M E F 2 A$ interaction and define the PPAR $\beta$ versus PPAR $\alpha$ specificity in this response. The $\alpha$ subunit of the AMPK complex was chosen for these experiments, given that this subunit has recently been shown to interact with PPAR $\beta$ (Narkar et al. 2008). HEK293 cells were cotransfected with expression vectors for PPAR $\beta$, PPAR $\alpha$, Flag-MEF2A, and/or Myc-AMPK $\alpha 2$. Anti-Flag was found to coimmunoprecipitate PPAR $\beta$ and endogenous $\mathrm{AMPK} \alpha$ (Fig. 4A). Using AMPK $\alpha$ as the immunoprecipitation target, $\operatorname{PPAR} \beta$, but not $\operatorname{PPAR} \alpha$, was pulled down (Fig. 4B). To determine the in vivo relevance of these interactions, co-IP studies with anti-PPAR $\alpha$ or anti-PPAR $\beta$ antibodies were conducted with extracts of gastrocnemius muscle from the MCK-PPAR lines. PPAR $\beta$, but not $\operatorname{PPAR} \alpha$, interacted with endogenous AMPK $\alpha 2$ (Fig. 4C).

Lastly, to determine whether endogenous AMPK localizes to the region of the $L d h b$ promoter containing the MEF2-binding site, additional ChIP experiments were conducted in primary skeletal myotubes. Anti-AMPK $\alpha 2$ precipitated this region of chromatin in response to activation of AMPK (AICAR) but not in response to PPAR $\beta$ ligand (Fig. 4D). Taken together, these results suggest that 

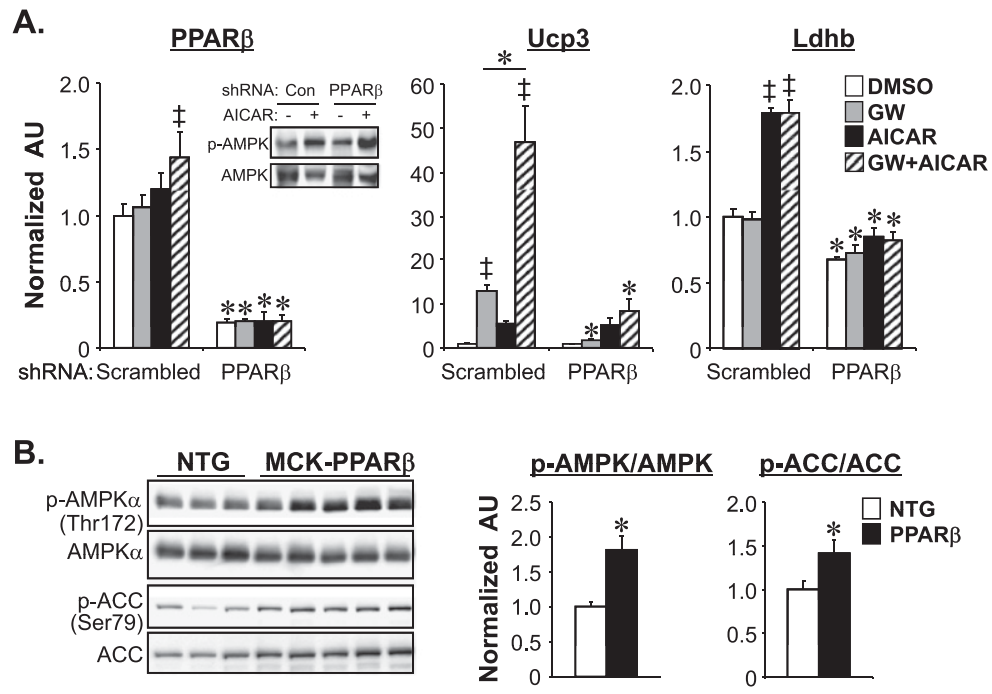

C.
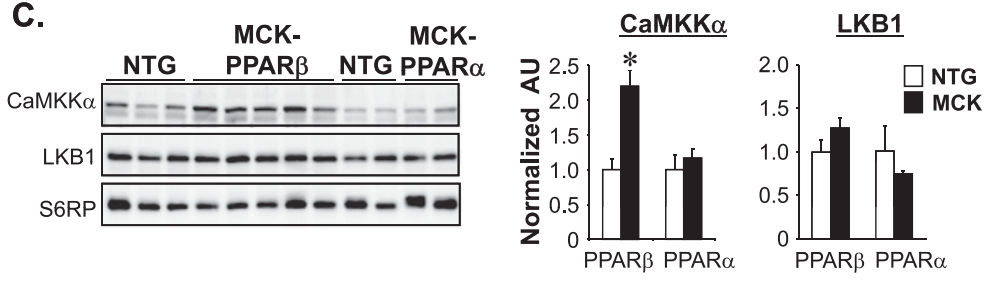

Figure 2. PPAR $\beta$ activates and cooperates with $\mathrm{AMPK} \alpha$ to activate $L d h b$ gene expression via a ligandindependent mechanism. (A) Results of qRT-PCR analysis for primary mouse myotubes after infection with adenovirus expressing specific or scrambled shRNAs as indicated. Forty-eight hours post-infection, myotubes were treated for $24 \mathrm{~h}$ with DMSO (vehicle), $0.5 \mu \mathrm{M}$ GW501516 (GW), 1 mM AICAR, or GW + AICAR as indicated in the key. Values represent mean ( \pm SEM) arbitrary units (AU) normalized $(=1.0)$ to the value of DMSO-treated scrambled shRNA $(n=3) .\left(^{\star}\right) P<0.05$ versus the corresponding scrambled shRNA; $(\ddagger) P$ $<0.05$ versus DMSO control. (Inset) Western blot analysis confirms an increase in $\mathrm{p}-\mathrm{AMPK} \alpha$ levels in myotubes treated with AICAR for $30 \mathrm{~min}$. (B, left) Results of Western blot analysis performed on extracts of gastrocnemius muscle isolated from NTG or MCK-PPAR $\beta$ mice using p-AMPK $\alpha$ (Thr 172), AMPK $\alpha$, p-ACC (Ser 79), or total ACC antibodies. (Right) Quantification of the p-AMPK/AMPK and p-ACC/ACC signal ratios ( $n=8$ mice in each group) normalized $(=1.0)$ to the NTG control. $(C$, left $)$ Results of Western blot analysis performed on gastrocnemius muscle extracts using CaMKK $\alpha$, LKB1, and S6RP (control) antibodies. (Right) Quantification of the Western blot signals corrected to S6RP $(n \geq 3$ mice in each group). Values represent mean $( \pm$ SEM) shown as arbitrary units $(\mathrm{AU})$ normalized $(=1.0)$ to the value of NTG control. $\left(^{\star}\right) P<0.05$ compared with NTG.

PPAR $\beta$, but not PPAR $\alpha$, interacts directly with activated AMPK to occupy the $L d h b$ promoter in cooperation with MEF2A.

To explore functional correlates of the PPAR $\beta / M E F 2 /$ AMPK interaction, a series of cell cotransfection studies were conducted using a MEF2 reporter containing three MEF2-responsive DNA elements multimerized upstream of a thymidine kinase $(t k)$ promoter driving a luciferase reporter, $\left[\mathrm{MEF} 2_{M E F 2 A}\right]_{3}$-tk-Luc (Zhu and Gulick 2004). In the presence of MEF2A, [MEF2 $\left.2_{M E F 2 A}\right]_{3}-t k$-Luc was not activated by either PPAR $\beta$ or AMPK $\alpha 2$ alone, but when expressed together, synergistic activation was observed (Fig. 5A). PPAR $\beta$ and AMPK $\alpha 2$ also synergized on a Gal4-MEF2A reporter, indicating that PPAR $\beta$ can coactivate MEF2 with AMPK without binding DNA (Fig. 5B). In contrast, and as predicted by the binding studies, $\mathrm{AMPK} \alpha 2$ did not activate either reporter with PPAR $\alpha$ (Fig. 5A,B). These findings indicate that PPAR $\beta$ is capable of activating $L d h b$ gene transcription via MEF2A in cooperation with AMPK, likely in a ligand-independent manner.

\section{MCK-PPAR $\beta$ muscle is reprogrammed for increased capacity for glucose uptake, storage, and oxidation}

The capacity of muscle to import, store, and utilize glucose is an important determinant of endurance and sprint exercise performance. Therefore, we next sought to determine whether a broad program of muscle glucose metabolism was activated in MCK-PPAR $\beta$ muscle. Pre-exercise muscle glycogen levels were significantly increased in MCK-
PPAR $\beta$, but not MCK-PPAR $\alpha$, mice (Fig. 6A,B). Glycogen levels were depleted after run to exhaustion in both groups (Fig. 6B), indicating that the MCK-PPAR $\beta$ mice used the high glycogen stores as fuel during exercise. Levels of total cellular GLUT4 protein and plasma
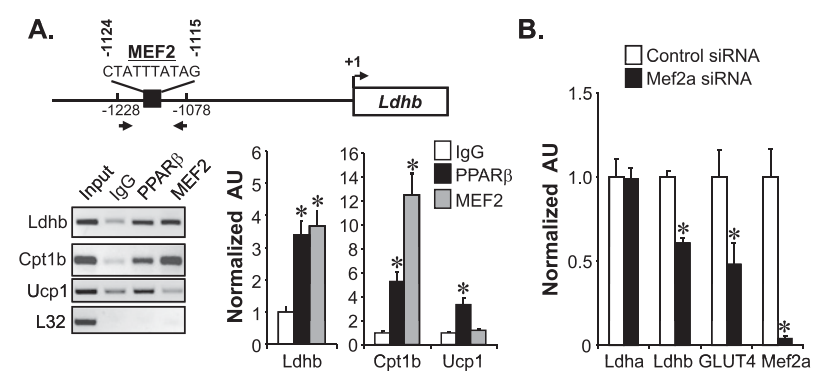

Figure 3. PPAR $\beta$ and MEF2 bind to the $L d h b$ promoter. $(A)$ The results of ChIP assays performed on primary mouse myotubes following infection with Ad-PPAR $\beta$. Schematic shows PCR primer set location $(-1228$ and -1078$)$ and the putative MEF2-binding site relative to the $L d h b$ promoter transcription start site $(=+1)$. (Left) Results of representative gel analysis showing relative binding (PCR results) to $L d h b, C p t 1 b$, and $U c p 1$ promoters and control (L32) promoter. Antibodies (or IgG control) are shown at the top. (Right) Graphs display mean SYBR Green-based quantification of ChIP normalized to IgG control $(n=3) .\left(^{\star}\right) P<0.05$ versus IgG control. $(B)$ Results of qRT-PCR analysis for primary mouse myotubes after transfection with Mef2a siRNAs or scrambled control siRNAs as indicated. Values represent mean $( \pm$ SEM) shown as arbitrary units $(\mathrm{AU})$ normalized $(=1.0)$ to the value of control siRNAs $(n=4) .\left(^{\star}\right) P<0.05$ versus control. 


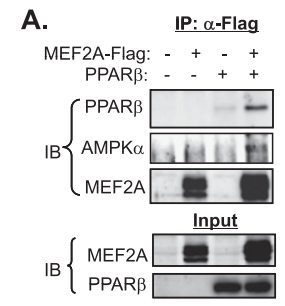

C.

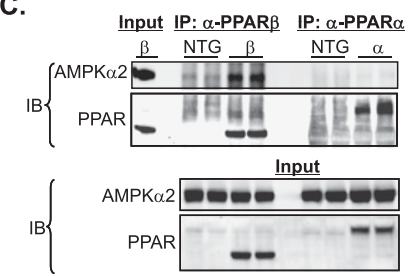

B.

IB

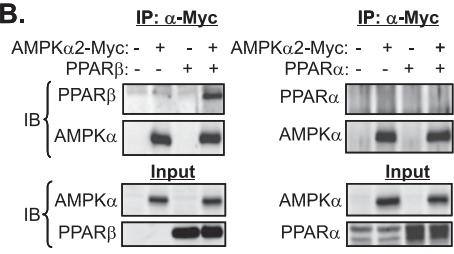

IP: $\alpha$-Myc $\quad$ IP: $\alpha$-Myc

PPARB: -+++ AMPKa2-MyC: -++

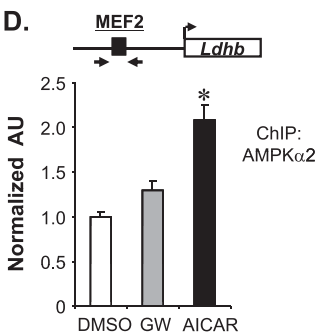

Figure 4. AMPK-PPAR $\beta-M E F 2$ interaction. $(A, B)$ Co-IP experiments were performed by cotransfecting Myc-AMPK $\alpha 2$, PPAR $\beta$, $\operatorname{PPAR} \alpha$, and/or Flag-MEF2A in HEK293 cells as indicated at the top. Antibodies against the Myc or Flag epitope were used for coIP. The extracts (Input) from the HEK293 cells and the proteins from the immunoprecipitation were analyzed by immunoblotting (IB). Representative results for co-IP (repeated at least twice) are shown. $(C)$ Co-IP results with extracts prepared from gastrocnemius muscle extracts prepared from indicated mice using antiPPAR $\beta$ or anti-PPAR $\alpha$ antibodies $(n=4$ per group). (D) AMPK $\alpha 2$ ChIP assays performed on primary mouse myotubes following infection with Ad-PPAR $\beta$. Myotubes were treated for $6 \mathrm{~h}$ with DMSO (vehicle), $0.5 \mu \mathrm{M}$ GW501516 (GW), or $1 \mathrm{mM}$ AICAR. Schematic shows PCR primer set location on the $L d h b$ promoter. The graph displays mean SYBR Green-based quantification of AMPK-ChIP/IgG-ChIP normalized to DMSO $(=1.0)$ control $(n=3)$. (*) $P<0.05$ compared with DMSO control.

membrane-associated GLUT4 (Fig. 6C,D) were significantly increased in MCK-PPAR $\beta$ muscle. In contrast, and as shown previously (Finck et al. 2005), GLUT4 levels were reduced in MCK-PPAR $\alpha$ muscle (Fig. 6C). Consistent with these results, MCK-PPAR $\alpha$ mice developed marked hyperglycemia during exercise, whereas blood glucose levels declined with exercise in MCK-PPAR $\beta$ mice (Supplemental Table 1). Thus, PPAR $\beta$, but not PPAR $\alpha$, reprograms muscle for increased glucose uptake and storage.

A series of studies were next conducted to determine whether PPAR $\beta$-driven activation of $L d h b$ expression resulted in increased capacity for mitochondrial pyruvate oxidation in MCK-PPAR $\beta$ muscle. As has been shown for an independent muscle-specific PPAR $\beta$-VP16 line (Wang et al. 2004), electron microscopy revealed an increase in mitochondrial volume density and mitochondrial DNA levels in MCK-PPAR $\beta$ soleus muscle compared with NTG controls (Supplemental Fig. 6A,B). A similar increase in muscle mitochondrial volume density was also present in MCK-PPAR $\alpha$ muscle, together with myocyte lipid droplet accumulation (Supplemental Fig. 6A,B). Respiration rates were determined in mitochondria isolated from the hindlimb of the MCK-PPAR lines and corresponding NTG controls using pyruvate as a substrate. Pyruvate-driven state 3 (maximal ADP-stimulated) respi- ration rates were significantly higher in MCK-PPAR $\beta$ mitochondria compared with controls, an effect that was not seen with the MCK-PPAR $\alpha$ mice (Fig. 7A). In contrast, and consistent with the increased expression of genes involved in FAO in both lines, palmitoylcarnitine-driven state 3 respiration rates were increased in both MCKPPAR $\beta$ and MCK-PPAR $\alpha$ mice (Supplemental Fig. 6C).

To determine the effect of increasing the LDHB/LDHA ratio on cellular pyruvate oxidation, oxygen consumption rates (OCRs) were measured in skeletal myotubes following knockdown of Ldha expression. As predicted, increasing the LDHB/LDHA ratio stimulated OCRs under basal conditions and in the presence of the uncoupler FCCP (Fig. 7B). Importantly, these effects were dependent on the addition of pyruvate to the medium (Supplemental Fig. 7).

To assess the physiological impact of increased capacity for muscle glucose uptake and oxidation in MCK-PPAR $\beta$ mice, additional exercise testing was conducted. Sprint exercise performance depends, in part, on high capacity for glucose utilization. Therefore, we hypothesized that the MCK-PPAR $\beta$ mice would perform better than wild-type controls and MCK-PPAR $\alpha$ mice on a high-intensity ("wind sprint") exercise regimen protocol. Indeed, MCK-PPAR $\beta$ mice ran longer distances than corresponding NTG controls on this protocol (Fig. 7C). In contrast, MCK-PPAR $\alpha$ mice ran shorter distances than NTG controls. Strikingly,
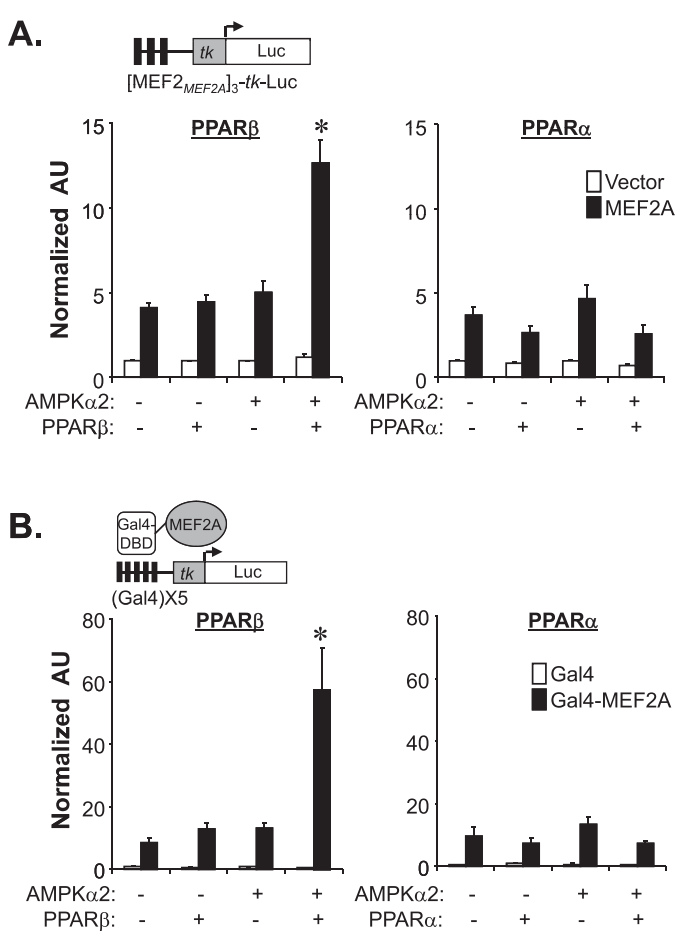

Figure 5. PPAR $\beta$ and AMPK synergistically coactivate MEF2A. $(A, B)$ Values represent mean $( \pm$ SEM) firefly/renilla luciferase activity shown as arbitrary units (AU) normalized $(=1.0)$ to vector control in HEK293 cells after cotransfection with expression vectors indicated and either the $\left[\mathrm{MEF} 2_{M E F 2 A}\right]_{3}-t k$-Luc or five-copy Gal4-Luc (pG5Luc) reporters. All values represent the results of a minimum of three separate experiments done in triplicate. $\left({ }^{\star}\right) P$ $<0.05$ compared with MEF2A or Gal4-MEF2A alone. 
A.
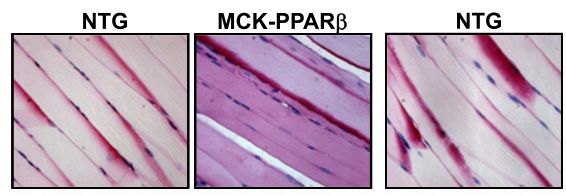

B.

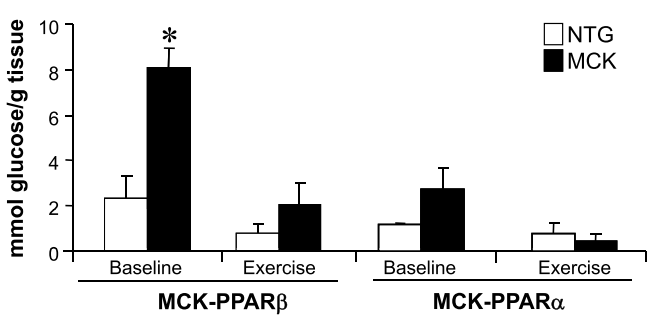

C.
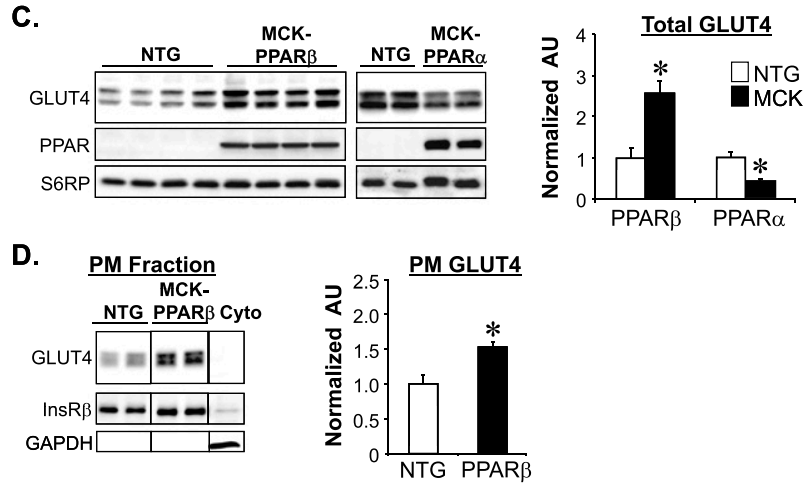

Figure 6. Increased glycogen stores in MCK-PPAR $\beta$ muscle parallel-enhanced expression of GLUT4 protein. $(A)$ Representative images of PAS staining of sections prepared from gastrocnemius muscles of 12- to 14-wk-old male MCK-PPAR $\beta$, MCK$\operatorname{PPAR} \alpha$, and NTG littermates at baseline (in the absence of exercise). (B) Bars represent mean glycogen levels (mmoles of glucose per gram of tissue) ( \pm SEM) determined enzymatically (amyloglucosidase digestion) at baseline and after high-intensity run-to-exhaustion protocol (Exercise). (C, left) Results of Western blot analysis performed with gastrocnemius muscle total protein extracts prepared from indicated mice using GLUT4, PPAR $\beta$, PPAR $\alpha$, or S6RP (control) antibodies. (Right) Quantification of the blotting results (corrected to S6RP levels; $n \geq 5$ mice in each group). Values represent mean ( \pm SEM) shown as arbitrary units (AU) normalized $(=1.0)$ to the value of NTG controls. $(D$, left $)$ Results of Western blot analysis of the plasma membrane (PM) fraction of gastrocnemius muscle lysate from NTG or MCK-PPAR $\beta$ mice using GLUT4, insulin receptor $\beta$ subunit (InsR $\beta$; membrane control), or GAPDH (cytosol control) antibodies. Cytosolic fraction (Cyto) is shown to confirm purity. Note that the lanes were run on the same gel but were noncontiguous. (Right) Quantification of the plasma membrane (PM) GLUT4 levels (corrected to InsR $\beta)(n \geq 6$ mice in each group). $\left({ }^{\star}\right) P<0.05$ versus NTG.

despite running longer, levels of blood lactate following exercise were lower in MCK-PPAR $\beta$ mice compared with NTG littermate controls, consistent with increased diversion of pyruvate into mitochondrial oxidation (Table 1). In stark contrast, lactate levels increased post-exercise in MCK-PPAR $\alpha$ mice (Table 1).

To further evaluate the muscle fuel utilization preference of MCK-PPAR $\beta$ mice during exercise, respiratory exchange ratio (RER) and oxygen utilization $\left(\mathrm{VO}_{2}\right)$ were measured during a run-to-exhaustion exercise protocol. Consistent with a shift to muscle glucose oxidation, the RER increased to $\sim 1.0$ with exercise in both MCKPPAR $\beta$ and the NTG control group, indicative of a switch to carbohydrates as the chief fuel (Supplemental Fig. 8A). Despite exercising significantly longer (and consuming more oxygen) compared with the control group, the MCK-PPAR $\beta$ mice maintained RER at $\sim 1.0$ during the entire exercise period (Supplemental Fig. 8A). Interestingly, whereas the MCK-PPAR $\beta$ mice consumed more
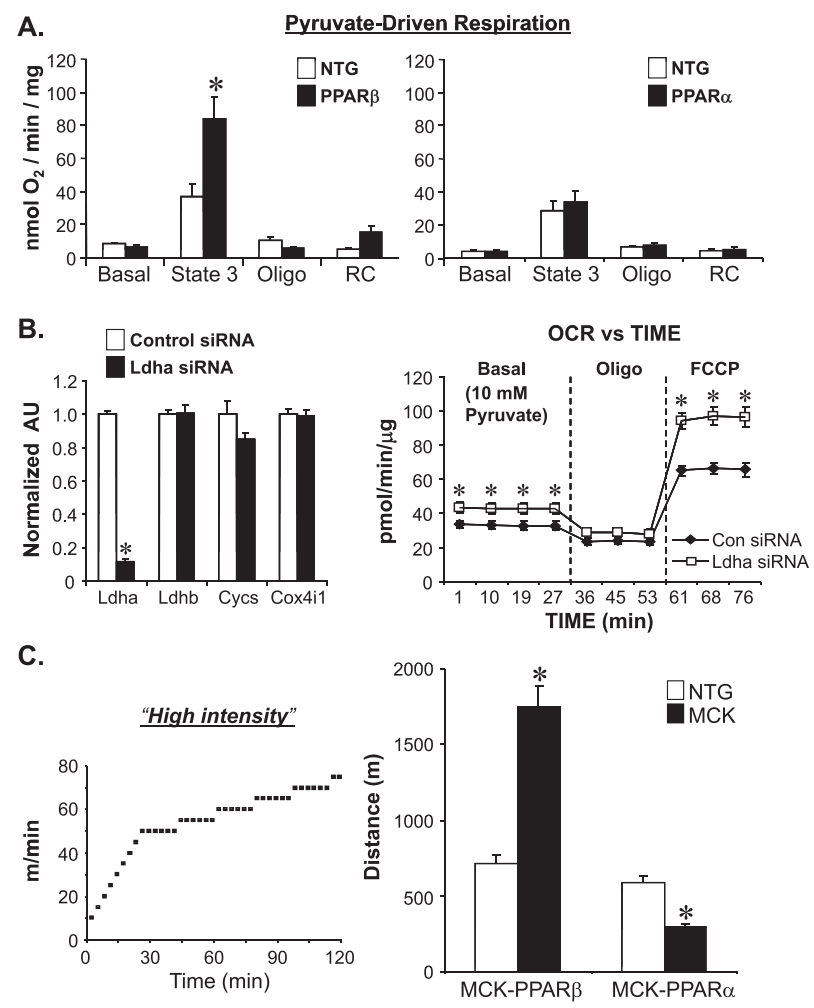

Figure 7. MCK-PPAR $\beta$ mice exhibit enhanced high-intensity exercise performance. (A) Respiration rates determined from mitochondria isolated from hindlimb muscle of indicated genotypes using pyruvate as substrate. ADP-dependent respiration (state 3 ), oligomycin-induced state 4 (oligo) and the respiratory control ratio $(\mathrm{RC})$ are shown. The increase in state 3 respiration in MCK-PPAR $\beta$ mitochondria is consistent with an increased capacity for pyruvate oxidation. $\left(^{\star}\right) P<0.05$ versus NTG. $(B$, left $)$ Results of qRT-PCR analysis for primary mouse myotubes after transfection with Ldha siRNAs or scrambled control siRNAs as indicated. (Right) OCRs in primary mouse myotubes transfected with Ldha siRNAs or control siRNAs. Basal OCR was first measured, followed by administration of $2 \mu \mathrm{M}$ oligomycin (Oligo, to inhibit ATP synthase) and then the uncoupler FCCP $(2 \mu \mathrm{M})$. OCR were measured in the presence of $10 \mathrm{mM}$ sodium pyruvate. Values represent mean $( \pm \mathrm{SEM}) ; n=5$ separate experiments done in five biological replicates. $\left(^{\star}\right) P<0.05$ versus control. $(C$, right) Bars represent mean running distance $( \pm \mathrm{SEM})$ for 12-wk-old male MCK-PPAR $\beta$ and MCK-PPAR $\alpha$ mice and littermate controls (NTG) during high-intensity (sprint) protocols (described in the Materials and Methods) on a motorized treadmill. (Left) Schematic depicts the speed change over time. $n=8-11$ mice in each group. $\left(^{\star}\right) P<0.05$ versus NTG. 
Table 1. Blood lactate levels in MCK-PPAR $\beta$ and MCK-PPAR $\alpha$ mice

\begin{tabular}{lcccc}
\hline & NTG & MCK-PPAR $\beta$ & NTG & MCK-PPAR $\alpha$ \\
\hline Run distance $(\mathrm{m})$ & $2086 \pm 201$ & $3559 \pm 186^{\mathrm{a}}$ & $1883 \pm 63$ & $1451 \pm 124^{\mathrm{a}}$ \\
Baseline lactate levels (mmol/L) & $3.9 \pm 0.2$ & $5.0 \pm 1.1$ & $2.9 \pm 0.5$ & $2.1 \pm 0.2$ \\
Post-exercise lactate levels (mmol/L) & $5.2 \pm 0.7$ & $3.9 \pm 0.6^{\mathrm{a}}$ & $5.0 \pm 1.1$ & $9.0 \pm 1.5^{\mathrm{a}}$ \\
\hline
\end{tabular}

Values represent the mean $( \pm \mathrm{SEM}) ; n=8-11$ mice in each group.

${ }^{\mathrm{a}} P<0.05$ versus NTG

oxygen during the exercise period (as reflected by an increase in $\Delta \mathrm{VO}_{2 \max }$, the maximal peak oxygen consumption $\left(\mathrm{VO}_{2 \max }\right)$ was not different between the groups (Supplemental Fig. 8B,C). Taken together, these results suggest that PPAR $\beta$ activates a gene regulatory program that increases the coupling of muscle glycolysis to glucose oxidation, allowing for greater ATP generation per mole of glucose burned.

\section{Discussion}

The capacity to burn fuel is a key determinant of muscle fitness. Exercise training triggers an adaptive metabolic response in muscle, leading to increased fuel burning capacity and the flexibility to switch between the chief substrates: FAs and glucose (Holloszy and Coyle 1984). In contrast, obesity and chronic disease, conditions that reduce physical activity, lead to a state in which the capacity of muscle to burn glucose is constrained (Mujika and Padilla 2001). Delineation of the gene regulatory mechanisms involved in the adaptive and maladaptive programming of muscle fuel metabolism could unveil new therapeutic targets aimed at common metabolic diseases such as obesity-related insulin resistance and diabetes. Here, we show that the nuclear receptor PPAR $\beta$, but not $\operatorname{PPAR} \alpha$, is capable of increasing capacity for muscle glucose oxidation by activating transcription of the $L d h b$ gene through a unique mechanism, in cooperation with AMPK and the transcription factor MEF2.

We found that PPAR $\beta$ activates a program that increases the coupling of glycolysis to glucose oxidation in muscle. This response involves PPAR $\beta$-mediated induction of $L d h b$ gene transcription and repression of $L d h a$ gene expression, resulting in an increase in the LDHB/ LDHA isoenzyme ratio. The LDHB isoenzyme functions to convert lactate to pyruvate; LDHA favors the opposite reaction to produce lactate. Notably, exercise training is known to increase muscle LDHB/LDHA ratio, increasing capacity to fully catabolize glucose for maximal ATP production (Hittel et al. 2005). Several lines of evidence presented here support the conclusion that PPAR $\beta$, but not $\operatorname{PPAR} \alpha$, drives a gene regulatory program that increases capacity for muscle glucose oxidation. First, activity of LDH isoenzymes containing LDHB is selectively activated in muscle extracts prepared from MCK-PPAR $\beta$, but not MCK-PPAR $\alpha$, mice. Second, capacity for glucose uptake, glycogen storage, and mitochondrial pyruvate oxidation is increased in MCK-PPAR $\beta$ muscle compared with MCK-PPAR $\alpha$ muscle. Third, the MCK-PPAR $\beta$ mice maintain a high RER throughout a bout of exercise to exhaustion. Interestingly, despite running longer and thus using more oxygen during exercise, the MCK-PPAR $\beta$ mice did not exhibit an increased absolute $\mathrm{VO}_{2 \max }$ compared with NTG controls. This interesting observation may reflect the persistent use of glucose (rather than fat) as an oxidative substrate, despite longer periods of exercise. Lastly, high-intensity exercise performance is increased and post-exercise blood lactate levels are decreased in MCK-PPAR $\beta$ mice compared with wild-type controls. In contrast, circulating lactate levels were abnormally increased in MCK-PPAR $\alpha$ mice following exercise.

We found that PPAR $\beta$ activates $L d h b$ gene transcription via a novel mechanism for nuclear receptors, involving cooperation with AMPK and the transcription factor MEF2A. The observed role of MEF2 is of interest given its known role in the regulation of muscle energy metabolism (Michael et al. 2001; Naya et al. 2002). Participation by AMPK in this mechanism is consistent with the observation that this kinase is activated by exercise (Woitaszewski et al. 2000b) and has been shown to cooperate with PPAR $\beta$ (Narkar et al. 2008). Moreover, emerging evidence indicates that activation of AMPK and related kinases is involved in muscle glucose uptake via a mechanism that is independent of insulin signaling, similar to the effects of exercise on glucose utilization (Witczak et al. 2008). We speculate that AMPK is a key trigger for the PPAR $\beta$-mediated activation of $L d h b$ gene transcription. The mechanism whereby AMPK is activated in MCK-PPAR $\beta$ muscle was not fully delineated in this study. Among the known upstream activators of AMPKLKB1 and CaMKK - we found only the latter to be induced in MCK-PPAR $\beta$ muscle. Specifically, CaMKK $\alpha$ protein levels were increased in MCK-PPAR $\beta$ muscle (CaMKK $\beta$ could not be detected, and therefore regulation could not be assessed).

The mechanisms whereby related nuclear receptors with similar DNA-binding domains regulate transcription of distinct target genes are poorly understood. Our results demonstrate that the $L d h b$ gene is activated by PPAR $\beta$, but not by PPAR $\alpha$, via a trans-activation mechanism that involves interaction with the transcription factor MEF2A in the absence of a classical PPAR DNA recognition element. This unique mechanism appears to be PPAR ligand-independent, but requires AMPK. The observed cooperativity with AMPK is consistent with recent results by Narkar et al. (2008) demonstrating that AMPK $\alpha$ interacts with PPAR $\beta$ to activate PPAR targets in muscle. However, in this previous study, AMPK/PPAR $\beta$ cooperativity was enhanced by ligand, in contrast to our results with the $L d h b$ gene. It is tempting to speculate that in certain circumstances, the effects of AMPK or other signaling pathways can substitute for ligand in the 
activation of a subset of PPAR $\beta$ targets. Our results also suggest that the PPAR $\beta$ versus $\operatorname{PPAR} \alpha$ specificity for activation of $L d h b$ gene transcription relates to specific interactions with AMPK $\alpha 2$ on the target promoter. The precise mechanisms involved in the activation of transcription via the MEF2A/PPAR $\beta / A M P K \alpha$ complex were not fully determined in this study. Recently, AMPK was shown to phosphorylate histone $\mathrm{H} 2 \mathrm{~B}$, suggesting one possible mechanism (Bungard et al. 2010). It is also possible that the cooperative interaction releases MEF2 from suppressive effects of repressors such as histone deacetylases (McGee et al. 2008). Consistent with this latter notion, we showed that activation of AMPK in $\mathrm{C} 2 \mathrm{C} 12$ myoblasts does indeed shift HDAC5 from nucleus to cytoplasm (data not shown). Future studies aimed at assessing changes in protein acetylation in the local vicinity of the PPAR $\beta / \mathrm{AMPK} \alpha /$ MEF2A complex will likely require genome-wide chromatin surveys.

In conclusion, our results suggest a model in which activation of AMPK, such as occurs with exercise, triggers the assembly of a transcriptional activation complex containing AMPK and PPAR $\beta$ tethered to MEF2A to regulate transcription of the $L d h b$ gene and likely a larger subset of metabolic gene targets. Further delineation of the mechanisms unveiled here could lead to strategies to develop selective PPAR-based metabolic modulators with pathway, or possibly even target, specificity.

\section{Materials and methods}

\section{Generation of MCK-PPAR $\beta$ transgenic mice}

A DNA construct containing a 1.0-kb PPAR $\beta$ cDNA was cloned downstream from the skeletal muscle MCK promoter (kind gift of E.N. Olson, University of Texas Southwestern). Transgenic mice were generated by microinjection of the MCK-PPAR $\beta$ construct into fertilized one-cell C57BL/6 × CBA/J F1 embryos. Three independent lines were generated, exhibiting different levels of transgenic expression as measured by Northern and Western blot (Supplemental Fig. 1A). Unless specifically indicated, the results described here were generated using the high-expressing MCKPPAR $\beta$ line (HE), compared with the previously generated highexpressing MCK-PPAR $\alpha$ line (Finck et al. 2005). The animal data represent studies with MCK-PPAR mouse lines (hybrid strain, B6/CBA), with the following specific exceptions: MCK-PPAR $\alpha$ mice in a C57BL/6J pure strain were used for immunoblotting (Figs. 2C, 4C, 6C), qRT-PCR (Fig. 1B; Supplemental Fig. 5), and LDH isoenzyme (Fig. 1C; Supplemental Fig. 3) experiments. NTG controls were used in all cases. Of note, the majority of the phenotypic characterization of these mice was performed in the hybrid strain (B6/CBA) for both MCK-PPAR $\alpha$ and MCKPPAR $\beta$. In addition, several gene expression readouts, including the regulation of $L d h a$ and $L d h b$ compared with corresponding nontransgenic controls, were similar in pure B6 backgrounds compared with the hybrid strain for both MCK-PPAR $\alpha$ and MCK-PPAR $\beta$ lines (data not shown).

\section{Animal studies}

Male and female MCK-PPAR mice and NTG controls ( $\sim 25-30 \mathrm{~g}$ of body weight; $8-16$ wk of age) were used for all studies. Animal studies were conducted in strict accordance with the NIH guidelines for humane treatment of animals.

\section{Mitochondrial respiration studies}

Skeletal muscle mitochondria were isolated from hindlimbs of MCK-PPAR mice and NTG controls as previously described (Zechner et al. 2010). Respiration rates of the mitochondrial isolate containing $0.5 \mathrm{mg}$ of protein were determined at $30^{\circ} \mathrm{C}$ using an optical probe (Oxygen FOXY Probe, Ocean Optics) in a 2-mL sealed, continuously stirred respiration chamber, as previously described (Leone et al. 2005). Respiration was determined using pyruvate and palmitoylcarnitine as substrates. Following measurement of basal respiration, state 3 respiration was determined by exposing mitochondria to $1 \mathrm{mM}$ ADP. Uncoupled respiration was evaluated following the addition of oligomycin $(1 \mu \mathrm{g} /$ $\mathrm{mL}$ ) to inhibit ATP synthase. The solubility of oxygen in the respiration buffer at $30^{\circ} \mathrm{C}$ was taken as $230 \mathrm{nmol}$ of oxygen per milliliter. Respiration rates were expressed as nanomoles of oxygen per minute per milligram of mitochondrial protein.

\section{Exercise studies}

Mice were acclimated (run for $9 \mathrm{~min}$ at 10 meters $[\mathrm{m}] / \mathrm{min}$ followed by $1 \mathrm{~min}$ at $20 \mathrm{~m} / \mathrm{min}$ ) to the treadmill for two consecutive days prior to the experimental protocol.

Low-intensity exercise (endurance) Fed mice were run for $1 \mathrm{~h}$ at $10 \mathrm{~m} / \mathrm{min}$, followed by an increase of $2 \mathrm{~m} / \mathrm{min}$ every $15 \mathrm{~min}$ until exhaustion (defined as remaining on the shock grid for five consecutive seconds).

High-intensity exercise (wind sprints) Fed mice were run for 1 $\mathrm{min}$, alternating with rest for $2 \mathrm{~min}$. Running intervals started at $10 \mathrm{~m} / \mathrm{min}$ and increased $5 \mathrm{~m} / \mathrm{min}$ each interval until a speed of $50 \mathrm{~m} / \mathrm{min}$ was reached. Then, speed was increased $5 \mathrm{~m} / \mathrm{min}$ every sixth interval until exhaustion.

Tail blood was taken before and after exercise and measured for glucose (B-GLUCOSE, Hemacue AB) and lactate (Lactate Pro Arkray). Tissue was dissected and immediately processed for glycogen analyses.

Peak $\mathrm{VO}_{2}$ and RER were determined as described previously (Calvo et al. 2008). Briefly, 3-mo-old male mice were placed in an enclosed treadmill attached to the Comprehensive Laboratory Animal Monitoring System (CLAMS; Columbus Instruments) for $30 \mathrm{~min}$ at a $0^{\circ}$ incline and $0 \mathrm{~m} / \mathrm{min}$. The mice were then challenged with $1.5-\mathrm{min}$ intervals of increasing speed at a $15^{\circ}$ incline. The increasing speeds used in the protocol were 10, 14, $18,22,26,28,30,32,34,36,38,40,42,44$, and $46 \mathrm{~m} / \mathrm{min}$. Measurements were collected before the exercise challenge, throughout the challenge, and following failure.

\section{Glycogen measurements}

Mouse gastrocnemius tissue was pulverized under liquid nitrogen and homogenized in a $0.3 \mathrm{M}$ perchloric acid solution. The muscle extract was then assayed with and without amyloglucosidase digestion (Sigma Aldrich) in $50 \mathrm{mM}$ sodium acetate $(\mathrm{pH}$ 5.5) and $0.02 \%$ BSA. Resulting changes in absorption at $340 \mathrm{nM}$ were compared with standards ranging from 0 to $80 \mu \mathrm{mol}$ of glucose. Results are presented as glucose released from glycogen, normalized to tissue weight.

\section{Histologic analyses and electron microscopy}

Mouse gastrocnemius was collected, immersed in Tissue-Tek O.C.T. Compound (Sakura Finetek USA, Inc.), and snap-frozen using Cytocool II (Richard-Allan Scientific) in a cryomold for sectioning. Sections were stained with Periodic Acid Schiff (PAS) 
to detect glycogen accumulation. Electron microscopy was performed as previously described (Zechner et al. 2010).

\section{Gene expression array studies}

Total RNA isolated from gastrocnemius muscle of 6-wk-old MCK-PPAR $\alpha$ (HE) or MCK-PPAR $\beta$ (HE) and NTG littermate mice was used for gene expression array studies performed as previously described (Huss et al. 2004). The Alvin Siteman Cancer Center's Multiplexed Gene Analysis Core at Washington University School of Medicine performed hybridization to Affymetrix mouse MOE430A chips. Affymetrix MAS 5.0 software was used for initial analysis and background normalization. Probe sets called "absent" by MAS 5.0 in both NTG and MCKPPAR were excluded. Two independent samples were analyzed. Signal intensity ratios were averaged from both samples and calculated as MCK-PPAR/NTG. A gene with a calculated fold change $\geq 1.5$ was considered an up-regulated gene target in the MCK-PPAR transgenic, and a gene with a fold change of $\leq 0.5$ was considered a down-regulated gene target. For pathway analysis, the filtered data sets were uploaded into GenMAPP software to review the biopathways using the Gene Ontology database. The gene array data discussed in this study have been deposited in NCBI's Gene Expression Omnibus (GEO) and are accessible through GEO series accession numbers GSE5777 (MCK-PPAR $\alpha$ ) and GSE29055 (MCK-PPAR $\beta)$.

\section{RNA and genomic DNA analyses}

Total RNA was isolated from mouse skeletal muscle using the RNAzol method (Tel-Test). Northern blot analysis was performed as previously described (Wende et al. 2005). Real-time qRT-PCR was performed using the Stratagene MX3005P detection system and reagents supplied by Stratagene. Specific oligonucleotide primers for target gene sequences are listed in Supplemental Table 2. Arbitrary units of target mRNA were corrected to expression of $36 \mathrm{b4}$.

Genomic/mitochondrial DNA was isolated using the RNAzol method, followed by back extraction with $4 \mathrm{M}$ guanidine thiocyanate, $50 \mathrm{mM}$ sodium citrate, and $1 \mathrm{M}$ Tris and an alcohol precipitation. Mitochondrial DNA content was determined by SYBR Green analysis (Stratagene). The levels of NADH dehydrogenase subunit 1 (mitochondrial DNA) were normalized to the levels of Lpl (genomic DNA). The primer sequences are noted in Supplemental Table 2.

\section{Antibodies and Western immunoblotting studies}

Antibodies directed against PPAR $\beta$ (K-20), PPAR $\alpha$ (H-98), insulin receptor $\beta$ subunit (InsR $\beta)$, and $\mathrm{CaMKK} \alpha$ (R-73) were purchased from Santa Cruz Biotechnology. Anti-GLUT4 antibody was a gift of M. Mueckler (Washington University); antibodies directed against p-AMPK $\alpha$ (Thr172), AMPK $\alpha$, p-ACC (Ser79), ACC, LKB1, and S6 ribosomal protein (S6RP) were purchased from Cell Signaling Technology; anti-GAPDH antibody was purchased from Abcam; and anti-AMPK $\alpha 2$ antibody was purchased from R\&D Systems.

Western immunoblotting studies were performed with whole gastrocnemius muscle lysates as previously described (Cresci et al. 1996). Detection was performed by measuring the chemiluminescent signal as assayed by SuperSignal Ultra (Pierce). Band intensities were quantified using the ChemiDoc (Bio-Rad) or FluorChemQ (Alpha Innotech).

\section{LDH isoenzyme analysis}

LDH isoenzyme patterns were determined as previously described (Salplachta and Necas 2000). Briefly, mouse gastrocnemius was homogenized in a solution of $0.9 \% \mathrm{NaCl}$ and $5 \mathrm{mM}$ Tris- $\mathrm{HCl}(\mathrm{pH}$ 7.4), and the lysates were centrifuged for $30 \mathrm{~min}$ at $15,000 \mathrm{~g}$ to remove the cellular debris. One-hundred micrograms of protein was loaded onto a $6 \%$ nondenaturing polyacrylamide gel. Following electrophoresis, the gel was placed in $10 \mathrm{~mL}$ of staining solution containing $0.1 \mathrm{M}$ sodium lactate, $1.5 \mathrm{mM} \mathrm{NAD}, 0.1 \mathrm{M}$ Tris- $\mathrm{HCl}$ (pH 8.6), $10 \mathrm{mM} \mathrm{NaCl}, 5 \mathrm{mM} \mathrm{MgCl} 2,0.03 \mathrm{mg} / \mathrm{mL}$ phenazinmethosulphate (PMS), and $0.25 \mathrm{mg} / \mathrm{mL}$ nitrobluetetrazolium (NBT). Protein extracted from mouse heart served as a positive control.

Preparation of subcellular membrane fractions from skeletal muscle

Subcellular membrane fractions were prepared using a modification of the Hirshman-modified Grimditch fractionation technique (Hirshman et al. 1990). Briefly, frozen mouse gastrocnemius were powdered in liquid nitrogen and homogenized in homogenization buffer (HB) (20 mM Tris, 1 mM EDTA, $255 \mathrm{mM}$ sucrose at $\mathrm{pH} 7.4)$ at $4^{\circ} \mathrm{C}$ using a $1-\mathrm{mL}$ dounce homogenizer. Homogenates were centrifuged at $16,800 \mathrm{~g}$ for $20 \mathrm{~min}$ at $4^{\circ} \mathrm{C}$, intracellular membranes (IMs) were isolated from supernatants, and plasma membranes were isolated from the pellets. Pellets containing plasma membranes were resuspended in $\mathrm{HB}$, followed by dounce homogenization, and were centrifuged at $16,800 \mathrm{~g}$ for $20 \mathrm{~min}$ at $4^{\circ} \mathrm{C}$. Pellets were resuspended in $\mathrm{HB}$, layered on a $1.12 \mathrm{M}$ sucrose cushion, and centrifuged in a TL-100 (Beckman Coulter) at $44,000 \mathrm{rpm}$ for $20 \mathrm{~min}$ at $4^{\circ} \mathrm{C}$. Plasma membranes at the interface between the sucrose cushion and buffer were collected, resuspended in $\mathrm{HB}$, and centrifuged in a TL-100.3 (Beckman Coulter) at 50,000 rpm for $10 \mathrm{~min}$ at $4^{\circ} \mathrm{C}$. Plasma membrane pellets were resuspended in SDS lysis buffer.

\section{Primary muscle cell culture}

Primary myoblasts (satellite cells) were isolated from wild-type mice as previously described (Rando and Blau 1994). Briefly, mice were killed by $\mathrm{CO}_{2}$ inhalation, followed by cervical dislocation. Hindlimb muscles from both legs were removed. Minced tissue was digested in a collagenase/dispase $/ \mathrm{CaCl}_{2}$ solution for $1.5 \mathrm{~h}$ at $37^{\circ} \mathrm{C}$ in a shaking bath. Dulbecco's modified Eagle's medium (DMEM) supplemented with $10 \%$ fetal bovine serum (FBS) (PPM) was added, and samples were triturated gently before loading onto a Netwell filter $(70 \mu \mathrm{m} ; \mathrm{BD})$. Cell suspension was pelleted at $1000 \mathrm{rpm}$ for 5 min. Cells were resuspended in PPM and plated on an uncoated plate for differential plating. Cell suspension (nonadherent) was centrifuged at $1000 \mathrm{rpm}$ for $5 \mathrm{~min}$, and the pellet was resuspended in growth medium (GM) (Ham's F-10 medium supplemented with $20 \% \mathrm{FBS}$ and $2.5 \mathrm{ng} / \mathrm{mL} \mathrm{bFGF}$ ). Satellite cells were plated on collagen-coated flasks for expansion. Cells were fed daily with GM. For differentiation, plates were washed with PBS, refed with $2 \%$ horse-serum/DMEM differentiation medium, and refed daily.

\section{Adenoviral infection}

The adenoviral expression vector for PPAR $\beta$ shRNA was a generous gift from Dr. Zhidan Wu (Novartis). Primary muscle cells were infected with an adenovirus overexpressing GFP shRNA or PPAR $\beta$ shRNA as previously described (Kleiner et al. 2009) and harvested $72 \mathrm{~h}$ post-infection. Cells were treated with DMSO, GW501516 (0.5 $\mu \mathrm{M})$, AICAR (1 mM), or GW + AICAR for $24 \mathrm{~h}$ prior to harvest.

\section{RNAi experiments}

siRNAs (ON-TARGET plus SMARTpool, Dharmacon) targeting mouse Ldha and Mef2a were transfected into primary myoblasts 
at a final concentration of $20 \mathrm{nM}$ using HiPerFect transfection reagent (Qiagen) according to the manufacturer's instructions. Cells were then differentiated for $3 \mathrm{~d}$ prior to harvest.

\section{Oxygen consumption measurements}

Cellular OCRs were measured using the XF24 analyzer (Seahorse Bioscience, Inc.) per the manufacturer's protocol. The basal OCR was measured in XF Assay medium supplemented with or without $10 \mathrm{mM}$ sodium pyruvate (as indicated), following administration of $2 \mu \mathrm{M}$ oligomycin (to inhibit ATP synthase) or the addition of the uncoupler FCCP $(2 \mu \mathrm{M})$. Immediately after measurement, total protein levels were measured with the Micro BCA protein assay kit (Thermo Scientific) for data correction.

\section{Cell transfection and luciferase reporter assays}

pCMX, pCMX-PPAR $\beta$, pBOS, and pBOS-PPAR $\alpha$ vectors have been described previously (Robinson et al. 1998; Burkart et al. 2007). [MEF2 $\left.2_{M E F 2 A}\right]_{3}-t k$-Luc, pG5Luc (Zhu and Gulick 2004), pCMX-Gal4-MEF2A (Zhu and Gulick 2004), and pcDNA3.1-FlagMEF2A were generously provided by Dr. Tod Gulick (SanfordBurnham Medical Research Institute); pCMV-myc-hAMPK $\alpha 2$ was kindly provided by Dr. Ronald Evans (Salk Institute). HEK293 cells were cultured at $37^{\circ} \mathrm{C}$ and $5 \% \mathrm{CO}_{2}$ in DMEM supplemented with $10 \%$ FBS. Transient transfections in HEK293 cells were performed using FuGENE6 (Roche) as per the manufacturer's protocol. Briefly, $600 \mathrm{ng}$ of reporter was cotransfected with $100 \mathrm{ng}$ of nuclear receptor expression vectors and $25 \mathrm{ng}$ of CMV promoter-driven Renilla luciferase to control for transfection efficiency. Forty-eight hours after cotransfection, luciferase assay was performed using Dual-Glo (Promega) according to the manufacturer's recommendations. All transfection data are presented as the mean \pm standard error of the mean (SEM) for at least three separate transfection experiments done in triplicate.

\section{Immunoprecipitation}

Whole gastrocnemius muscle lysates from MCK-PPAR mice or lysate from HEK 293 cells $48 \mathrm{~h}$ post-transfection were used for coIP studies. HEK293 cells were collected in lysis buffer $(20 \mathrm{mM}$ Tris at $\mathrm{pH} 7.5,150 \mathrm{mM} \mathrm{NaCl}, 1 \mathrm{mM}$ EDTA, $1 \%$ TritonX-100, $1 \times$ Complete [Roche], $1 \mathrm{mM}$ PMSF) and lysed with a Branson sonicator (power 1, 50\% duty, 15 bursts). One microgram of M2 anti-Flag (Sigma) or anti-MYC (Millipore) antibodies were incubated with extract and protein G-conjugated agarose beads, and the immunoprecipitated proteins were analyzed by immunoblotting.

\section{ChIP assays}

ChIP assays were performed as previously described (Wende et al. 2005; Yang et al. 2009). Briefly, primary myotubes were cross-linked with $1 \%$ formaldehyde $(10 \mathrm{~min})$, and cells were collected and lysed. For AMPK ChIPs, myotubes were first fixed for $30 \mathrm{~min}$ with $0.5 \mathrm{mM}$ ethylene glycolbis succinimidylsuccinate (EGS) (Pierce). Chromatin fragmentation was performed by sonication using a Bioruptor (Diagenode). Proteins were immunoprecipitated by using anti-PPAR $\beta$ (K-20, Santa Cruz Biotechnology), anti-MEF2 (H-300, Santa Cruz Biotechnology), anti-AMPK $\alpha 2$ (R\&D Systems), or IgG control (Sigma). Following reversal of cross-linking, DNA was isolated (QIAquick PCR purification kit, Qiagen). qPCR products were assessed and measured using the Stratagene MX3005P detection system. Quantitative analysis was performed by the standard curve method and normalized to IgG control. Specific oligonucleotide primers for target regions are listed in Supplemental Table 3.

\section{Statistical analyses}

Data were analyzed by Student's $t$-test (two-tailed) or one-way ANOVA coupled to a Fisher's least-significant difference (LSD) post-hoc test when more than two groups were being compared. Data represent the mean $\pm S E M$, with a statistically significant difference defined as a value of $P<0.05$.

\section{Acknowledgments}

Special thanks to the Cardiometabolic Phenotyping Core (SanfordBurnham Medical Research Institute), especially Emily King and Rochelle Holt, for performing the $\mathrm{VO}_{2}$ studies; Genevieve DeMaria, Shonna Hyde, and Christine Lauretano for assistance with manuscript preparation; Lauren Kim for help with mitochondrial respiration studies; Zhen Jiang for advice on subcellular membrane fraction preparations; John W. Rumsey for expert technical assistance with primary muscle cell culture; Ling Lai for scientific critique and discussion; and Juliet L. Fong, Deanna Collia, Corin Riggs, Beatrice Alvarado, and Lauren Ashley Gabriel for assistance with the animal studies. This work was supported by NIH grant RO1-DK045416 and the Alvin J. Siteman Cancer Center at Washington University School of Medicine in St. Louis, MO (Molecular and Genomics Analysis Core, supported by NCI Cancer Center Support Grant P30 CA91842).

\section{References}

Baldan A, Relat J, Marrero PF, Haro D. 2004. Functional interaction between peroxisome proliferator-activated receptors- $\alpha$ and Mef-2C on human carnitine palmitoyltransferase $1 \beta$ (CPT1 1 ) gene activation. Nucleic Acids Res 32: 47424749.

Brandt JM, Djouadi F, Kelly DP. 1998. Fatty acids activate transcription of the muscle carnitine palmitoyltransferase I gene in cardiac myocytes via the peroxisome proliferatoractivated receptor $\alpha$. J Biol Chem 273: 23786-23792.

Bungard D, Fuerth BJ, Zeng PY, Faubert B, Maas NL, Viollet B, Carling D, Thompson CB, Jones RG, Berger SL. 2010. Signaling kinase AMPK activates stress-promoted transcription via histone H2B phosphorylation. Science 329: 1201-1205.

Burkart EM, Sambandam N, Han X, Gross RW, Courtois M, Gierasch CM, Shoghi K, Welch MJ, Kelly DP. 2007. Nuclear receptors $\operatorname{PPAR} \beta / \delta$ and $\operatorname{PPAR} \alpha$ direct distinct metabolic regulatory programs in the mouse heart. I Clin Invest 117: 3930-3939.

Burke LM, Hawley JA. 1999. Carbohydrate and exercise. Curr Opin Clin Nutr Metab Care 2: 515-520.

Calvo JA, Daniels TG, Wang X, Paul A, Lin J, Spiegelman BM, Stevenson SC, Rangwala SM. 2008. Muscle-specific expression of PPAR $\gamma$ coactivator- $1 \alpha$ improves exercise performance and increases peak oxygen uptake. J Appl Physiol 104: 13041312.

Coggan AR. 1991. Plasma glucose metabolism during exercise in humans. Sports Med 11: 102-124.

Cresci S, Wright LD, Spratt JA, Briggs FN, Kelly DP. 1996. Activation of a novel metabolic gene regulatory pathway by chronic stimulation of skeletal muscle. Am I Physiol 270: C1413-C1420.

DeFronzo RA, Gunnarsson R, Bjorkman O, Olsson M, Wahren J. 1985. Effects of insulin on peripheral and splanchnic glucose metabolism in noninsulin-dependent (type II) diabetes mellitus. J Clin Invest 76: 149-155.

Desvergne B, Wahli W. 1999. Peroxisome proliferator-activated receptors: Nuclear control of metabolism. Endocr Rev 20: 649-688. 
Finck BN, Lehman JJ, Leone TC, Welch MJ, Bennett MJ, Kovacs A, Han X, Gross RW, Kozak R, Lopaschuk GD, et al. 2002. The cardiac phenotype induced by PPAR $\alpha$ overexpression mimics that caused by diabetes mellitus. J Clin Invest 109: 121-130.

Finck BN, Bernal-Mizrachi C, Han DH, Coleman T, Sambandam N, LaRiviere LL, Holloszy JO, Semenkovich CF, Kelly DP. 2005. A potential link between muscle peroxisome proliferator-activated receptor- $\alpha$ signaling and obesity-related diabetes. Cell Metab 1: 133-144.

Gilde AJ, van der Lee KA, Willemsen PH, Chinetti G, van der Leij FR, van der Vusse GJ, Staels B, van Bilsen M. 2003. Peroxisome proliferator-activated receptor (PPAR) $\alpha$ and $\operatorname{PPAR} \beta / \delta$, but not PPAR $\gamma$, modulate the expression of genes involved in cardiac lipid metabolism. Circ Res 92: 518-524.

Goodyear LJ, Giorgino F, Balon TW, Condorelli G, Smith RJ. 1995. Effects of contractile activity on tyrosine phosphoproteins and PI 3-kinase activity in rat skeletal muscle. Am I Physiol 268: E987-E995.

Gulick T, Cresci S, Caira T, Moore DD, Kelly DP. 1994. The peroxisome proliferator-activated receptor regulates mitochondrial fatty acid oxidative enzyme gene expression. Proc Natl Acad Sci 91: 11012-11016.

Hargreaves M. 2004. Muscle glycogen and metabolic regulation. Proc Nutr Soc 63: 217-220.

Hawley JA. 2002. Adaptations of skeletal muscle to prolonged, intense endurance training. Clin Exp Pharmacol Physiol 29: 218-222.

Hawley SA, Pan DA, Mustard KJ, Ross L, Bain J, Edelman AM, Frenguelli BG, Hardie DG. 2005. Calmodulin-dependent protein kinase kinase- $\beta$ is an alternative upstream kinase for AMP-activated protein kinase. Cell Metab 2: 9-19.

Hayashi T, Wojtaszewski JF, Goodyear LJ. 1997. Exercise regulation of glucose transport in skeletal muscle. Am J Physiol 273: E1039-E1051.

Hirshman MF, Goodyear LJ, Wardzala LJ, Horton ED, Horton ES. 1990. Identification of an intracellular pool of glucose transporters from basal and insulin-stimulated rat skeletal muscle. J Biol Chem 265: 987-991.

Hittel DS, Kraus WE, Tanner CJ, Houmard JA, Hoffman EP. 2005. Exercise training increases electron and substrate shuttling proteins in muscle of overweight men and women with the metabolic syndrome. J Appl Physiol 98: 168-179.

Holloszy JO. 2005. Exercise-induced increase in muscle insulin sensitivity. I Appl Physiol 99: 338-343.

Holloszy JO, Coyle EF. 1984. Adaptations of skeletal muscle to endurance exercise and their metabolic consequences. I Appl Physiol 56: 831-838.

Holloszy JO, Kohrt WM, Hansen PA. 1998. The regulation of carbohydrate and fat metabolism during and after exercise. Front Biosci 3: D1011-D1027.

Holmes BF, Kurth-Kraczek EJ, Winder WW. 1999. Chronic activation of 5 -AMP-activated protein kinase increases GLUT-4, hexokinase, and glycogen in muscle. J Appl Physiol 87: 1990-1995

Huss JM, Kelly DP. 2004. Nuclear receptor signaling and cardiac energetics. Circ Res 95: 568-578.

Huss JM, Torra IP, Staels B, Giguere V, Kelly DP. 2004. Estrogenrelated receptor $\alpha$ directs peroxisome proliferator-activated receptor $\alpha$ signaling in the transcriptional control of energy metabolism in cardiac and skeletal muscle. Mol Cell Biol 24: 9079-9091.

Ivy JL, Holloszy JO. 1981. Persistent increase in glucose uptake by rat skeletal muscle following exercise. Am I Physiol 241: C200-C203.

Kleiner S, Nguyen-Tran V, Bare O, Huang X, Spiegelman B, Wu Z. 2009. PPAR $\delta$ agonism activates fatty acid oxidation via
PGC- $1 \alpha$ but does not increase mitochondrial gene expression and function. J Biol Chem 284: 18624-18633.

Leone TC, Weinheimer CJ, Kelly DP. 1999. A critical role for the peroxisome proliferator-activated receptor $\alpha(\operatorname{PPAR} \alpha)$ in the cellular fasting response: The PPAR $\alpha$-null mouse as a model of fatty acid oxidation disorders. Proc Natl Acad Sci 96: 7473-7478.

Leone TC, Lehman JJ, Finck BN, Schaeffer PJ, Wende AR, Boudina S, Courtois M, Wozniak DF, Sambandam N, BernalMizrachi C, et al. 2005. PGC- $1 \alpha$ deficiency causes multisystem energy metabolic derangements: Muscle dysfunction, abnormal weight control and hepatic steatosis. PLOS Biol 3: e101. doi: 10.1371/journal.pbio.0030101.

Luquet S, Lopez-Soriano J, Holst D, Fredenrich A, Melki J, Rassoulzadegan M, Grimaldi PA. 2003. Peroxisome proliferator-activated receptor $\delta$ controls muscle development and oxidative capability. FASEB J 17: 2299-2301.

Madrazo JA, Kelly DP. 2008. The PPAR trio: Regulators of myocardial energy metabolism in health and disease. $J$ Mol Cell Cardiol 44: 968-975.

McGee SL, van Denderen BJ, Howlett KF, Mollica J, Schertzer JD, Kemp BE, Hargreaves M. 2008. AMP-activated protein kinase regulates GLUT4 transcription by phosphorylating histone deacetylase 5. Diabetes 57: 860-867.

Michael LF, Wu Z, Cheatham RB, Puigserver P, Adelmant G, Lehman JJ, Kelly DP, Spiegelman BM. 2001. Restoration of insulin-sensitive glucose transporter (GLUT4) gene expression in muscle cells by the transcriptional coactivator PGC1. Proc Natl Acad Sci 98: 3820-3825.

Montagner A, Rando G, Degueurce G, Leuenberger N, Michalik L, Wahli W. 2011. New insights into the role of PPARs. Prostaglandins Leukot Essent Fatty Acids 85: 235-243.

Mujika I, Padilla S. 2001. Muscular characteristics of detraining in humans. Med Sci Sports Exerc 33: 1297-1303.

Narkar VA, Downes M, Yu RT, Embler E, Wang YX, Banayo E, Mihaylova MM, Nelson MC, Zou Y, Juguilon H, et al. 2008. AMPK and PPAR $\delta$ agonists are exercise mimetics. Cell 134: 405-415.

Naya FJ, Black BL, Wu H, Bassel-Duby R, Richardson JA, Hill JA, Olson EN. 2002. Mitochondrial deficiency and cardiac sudden death in mice lacking the MEF2A transcription factor. Nat Med 8: 1303-1309.

Ojuka EO, Nolte LA, Holloszy JO. 2000. Increased expression of GLUT-4 and hexokinase in rat epitrochlearis muscles exposed to AICAR in vitro. J Appl Physiol 88: 1072-1075.

Rando TA, Blau HM. 1994. Primary mouse myoblast purification, characterization, and transplantation for cell-mediated gene therapy. J Cell Biol 125: 1275-1287.

Ren JM, Semenkovich CF, Gulve EA, Gao J, Holloszy JO. 1994. Exercise induces rapid increases in GLUT4 expression, glucose transport capacity, and insulin-stimulated glycogen storage in muscle. J Biol Chem 269: 14396-14401.

Richter EA, Garetto LP, Goodman MN, Ruderman NB. 1982. Muscle glucose metabolism following exercise in the rat: Increased sensitivity to insulin. I Clin Invest 69: 785-793.

Robinson CE, Wu X, Morris DC, Gimble JM. 1998. DNA bending is induced by binding of the peroxisome proliferator-activated receptor $\gamma 2$ heterodimer to its response element in the murine lipoprotein lipase promoter. Biochem Biophys Res Commun 244: 671-677.

Salplachta J, Necas J. 2000. Lactate dehydrogenase isoenzyme pattern in tissues and serum of the calf. Acta Vet (Brno) 69: 267-275.

Schupp M, Lazar MA. 2010. Endogenous ligands for nuclear receptors: Digging deeper. J Biol Chem 285: 40409-40415. 
Gan et al.

Treadway JL, James DE, Burcel E, Ruderman NB. 1989. Effect of exercise on insulin receptor binding and kinase activity in skeletal muscle. Am J Physiol 256: E138-E144.

Vega RB, Huss JM, Kelly DP. 2000. The coactivator PGC-1 cooperates with peroxisome proliferator-activated receptor $\alpha$ in transcriptional control of nuclear genes encoding mitochondrial fatty acid oxidation enzymes. Mol Cell Biol 20: $1868-1876$.

Wang YX, Zhang CL, Yu RT, Cho HK, Nelson MC, BayugaOcampo CR, Ham J, Kang H, Evans RM. 2004. Regulation of muscle fiber type and running endurance by PPAR $\delta$. PLOS Biol 2: e294. doi: 10.1371/journal.pbio.0020294.

Wende AR, Huss JM, Schaeffer PJ, Giguere V, Kelly DP. 2005. PGC- $1 \alpha$ coactivates PDK4 gene expression via the orphan nuclear receptor ERR $\alpha$ : A mechanism for transcriptional control of muscle glucose metabolism. Mol Cell Biol 25: 10684-10694.

Wende AR, Schaeffer PJ, Parker GJ, Zechner C, Han DH, Chen MM, Hancock CR, Lehman JJ, Huss JM, McClain DA, et al. 2007. A role for the transcriptional coactivator PGC- $1 \alpha$ in muscle refueling. J Biol Chem 282: 36642-36651.

Witczak CA, Sharoff CG, Goodyear LJ. 2008. AMP-activated protein kinase in skeletal muscle: From structure and localization to its role as a master regulator of cellular metabolism. Cell Mol Life Sci 65: 3737-3755.

Wojtaszewski JF, Hansen BF, Kiens B, Richter EA. 1997. Insulin signaling in human skeletal muscle: Time course and effect of exercise. Diabetes 46: 1775-1781.

Woitaszewski JF, Hansen BF, Gade, Kiens B, Markuns JF, Goodyear LJ, Richter EA. 2000a. Insulin signaling and insulin sensitivity after exercise in human skeletal muscle. Diabetes 49: 325-331.

Woitaszewski JF, Nielsen P, Hansen BF, Richter EA, Kiens B. 2000b. Isoform-specific and exercise intensity-dependent activation of $5^{\prime}$-AMP-activated protein kinase in human skeletal muscle. I Physiol 528: 221-226.

Woods A, Dickerson K, Heath R, Hong SP, Momcilovic M, Johnstone SR, Carlson M, Carling D. 2005. Ca2+/calmodulindependent protein kinase kinase- $\beta$ acts upstream of AMPactivated protein kinase in mammalian cells. Cell Metab 2: 21-33.

Yang J, Williams RS, Kelly DP. 2009. Bcl3 interacts cooperatively with peroxisome proliferator-activated receptor $\gamma$ $(\operatorname{PPAR} \gamma)$ coactivator $1 \alpha$ to coactivate nuclear receptors estrogen-related receptor $\alpha$ and PPAR $\alpha$. Mol Cell Biol 29: 4091-4102.

Zechner C, Lai L, Zechner JF, Geng T, Yan Z, Rumsey JW, Collia D, Chen Z, Wozniak DF, Leone TC, et al. 2010. Total skeletal muscle PGC-1 deficiency uncouples mitochondrial derangements from fiber type determination and insulin sensitivity. Cell Metab 12: 633-642.

Zhu B, Gulick T. 2004. Phosphorylation and alternative premRNA splicing converge to regulate myocyte enhancer factor 2C activity. Mol Cell Biol 24: 8264-8275. 


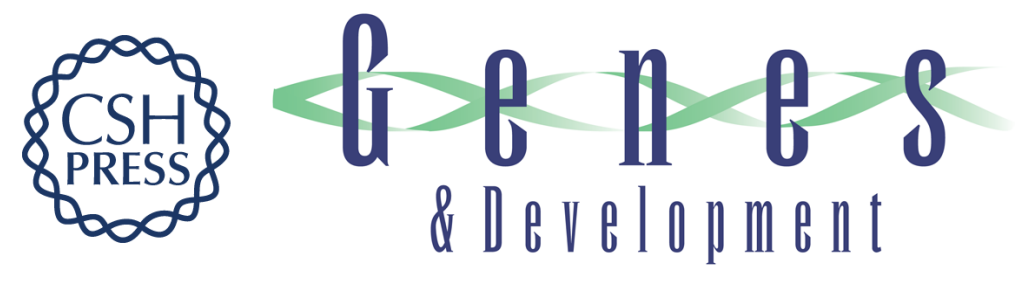

\section{The nuclear receptor PPAR $\beta / \delta$ programs muscle glucose metabolism in cooperation with AMPK and MEF2}

Zhenji Gan, Eileen M. Burkart-Hartman, Dong-Ho Han, et al.

Genes Dev. 2011, 25: originally published online December 1, 2011

Access the most recent version at doi:10.1101/gad.178434.111

\section{Supplemental http://genesdev.cshlp.org/content/suppl/2011/12/02/gad.178434.111.DC1 Material}

References This article cites 59 articles, 21 of which can be accessed free at: http://genesdev.cshlp.org/content/25/24/2619.full.html\#ref-list-1

\section{License}

Email Alerting

Receive free email alerts when new articles cite this article - sign up in the box at the top Service 